\title{
Development of Tyrosine-Based Radiotracer ${ }^{99 \mathrm{~m}}$ Tc-N4-Tyrosine for Breast Cancer Imaging
}

\author{
Fan-Lin Kong, ${ }^{1}$ Mohammad S. Ali, ${ }^{1}$ Alex Rollo, ${ }^{1}$ Daniel L. Smith, ${ }^{2}$ Yinhan Zhang, ${ }^{1}$ \\ Dong-Fang Yu, ${ }^{1}$ and David J. Yang ${ }^{1}$ \\ ${ }^{1}$ Department of Experimental Diagnostic Imaging, The University of Texas MD Anderson Cancer Center, Houston,
TX 77030, USA
${ }^{2}$ Department of Imaging Physics, The University of Texas MD Anderson Cancer Center, Houston, TX 77030, USA
}

Correspondence should be addressed to Fan-Lin Kong, kongfanlin2007@gmail.com

Received 11 November 2011; Accepted 13 December 2011

Academic Editor: Lie-Hang Shen

Copyright ( 92012 Fan-Lin Kong et al. This is an open access article distributed under the Creative Commons Attribution License, which permits unrestricted use, distribution, and reproduction in any medium, provided the original work is properly cited.

\begin{abstract}
The purpose of this study was to develop an efficient way to synthesize ${ }^{99 \mathrm{~m}} \mathrm{Tc}-\mathrm{O}-[3-(1,4,8,11$-tetraazabicyclohexadecane)-propyl]tyrosine ( ${ }^{99 \mathrm{~m}} \mathrm{Tc}-\mathrm{N} 4$-Tyrosine), a novel amino acid-based radiotracer, and evaluate its potential in breast cancer gamma imaging. Precursor N4-Tyrosine was synthesized using a 5-step procedure, and its total synthesis yield was 38\%. It was successfully labeled with ${ }^{99 \mathrm{~m}} \mathrm{Tc}$ with high radiochemical purity $(>95 \%)$. Cellular uptake of ${ }^{99 \mathrm{~m}} \mathrm{Tc}-\mathrm{N} 4$-Tyrosine was much higher than that of ${ }^{99 \mathrm{~m}} \mathrm{Tc}$ $\mathrm{N} 4$ and the clinical gold standard ${ }^{18} \mathrm{~F}$-2-deoxy-2-fluoro-glucose $\left({ }^{18} \mathrm{~F}-\mathrm{FDG}\right)$ in rat breast tumor cells in vitro. Tissue uptake and dosimetry estimation in normal rats revealed that ${ }^{99 \mathrm{~m}} \mathrm{Tc}-\mathrm{N} 4$-Tyrosine could be safely administered to humans. Evaluation in breast tumor-bearing rats showed that although ${ }^{99 \mathrm{~m}} \mathrm{Tc}-\mathrm{N} 4$-Tyrosine appeared to be inferior to ${ }^{18} \mathrm{~F}$-FDG in distinguishing breast tumor tissue from chemical-induced inflammatory tissue, it had high tumor-to-muscle uptake ratios and could detect breast tumors clearly by planar scintigraphic imaging. ${ }^{99 \mathrm{~m}} \mathrm{Tc}-\mathrm{N} 4-$ Tyrosine could thus be a useful radiotracer for use in breast tumor diagnostic imaging.
\end{abstract}

\section{Introduction}

${ }^{18} \mathrm{~F}$-2-deoxy-2-fluoro-glucose ( ${ }^{18} \mathrm{~F}$-FDG), an ${ }^{18} \mathrm{~F}$-labeled glucose analog, is a gold standard for positron emission tomography (PET) in cancer diagnosis. However, ${ }^{18}$ F-FDGPET has several limitations that can result in false positive or negative diagnoses, and its ability to predict tumor response to chemotherapy or radionuclide therapy is poor [1]. For instance, ${ }^{18}$ F-FDG cannot distinguish tumor tissue from inflammatory or normal brain tissues because each type of tissue has high glucose consumption. Therefore, radiolabeled amino acids have been developed as an alternative to ${ }^{18} \mathrm{~F}$ FDG in diagnostic imaging of cancer. Their use in tumor detection is based on an increased uptake of amino acids in tumor cells, which is assumed to reflect enhanced amino acid transport, metabolism, and protein synthesis [2].

Among all radiolabeled amino acids, aromatic ones such as tyrosine and its derivatives are more suitable for use in cancer diagnostic imaging given their readily alterable chemistry and favorable biological characteristics. To date, tyrosine and its $\alpha$-methyl-substituted analog $\alpha$-methyl tyrosine (AMT) have been successfully labeled with ${ }^{11} \mathrm{C},{ }^{18} \mathrm{~F}$, and ${ }^{124 / 125}$ I for PET imaging, as well as ${ }^{123 / 131}$ I for singlephoton emission computed tomography (SPECT) imaging, respectively [2-7]. Most of these radiolabeled tyrosine analogs show promise in preclinical and clinical research in diagnostic tumor imaging, especially for brain tumors. They have also been successfully applied to imaging breast cancer, which is the most common malignancy among women in the world. For instance, ${ }^{11} \mathrm{C}$-labeled tyrosine appears to be better than ${ }^{18}$ F-FDG for breast cancer imaging because of its lower uptake in noncancerous fibrocystic disease [8].

However, most existing radiolabeled tyrosine derivatives require an on-site cyclotron to produce the radioisotope, which is inconvenient and costly. In addition to that, the radioisotopes have either a too short (e.g., 20 minutes for ${ }^{11} \mathrm{C}$ ) or too long (e.g., 57.4 days for ${ }^{125} \mathrm{I}$ ) half-life, making them impractical for clinical use. Furthermore, 
iodine-labeled compounds are not stable in vivo because of deiodination. So far, ${ }^{18} \mathrm{~F}$ has the most appropriate halflife (110 minutes); however, the radiosynthesis yield of ${ }^{18} \mathrm{~F}$ labeled radiotracers is relatively low, apparently because of the electrophilic fluorination and tedious purification of ${ }^{18} \mathrm{~F}$. Therefore, a radiotracer with simpler chemistry and an affordable isotope that can be used clinically in most major medical facilities is needed.

Technetium- $99 \mathrm{~m}\left({ }^{99 \mathrm{~m}} \mathrm{Tc}\right)$ is an ideal radioisotope for diagnostic imaging studies because of its favorable physical characteristics. It emits a $140 \mathrm{keV}$ gamma ray in $89 \%$ abundance, which is commonly used in gamma and SPECT imaging. The half-life of ${ }^{99 \mathrm{~m}} \mathrm{Tc}$ is 6.02 hours, allowing serial images and, thus, overcoming a drawback of ${ }^{18} \mathrm{~F}$ [9]. Unlike most cyclotron-produced radionuclides, which use covalent chemistry for labeling, ${ }^{99 \mathrm{~m}} \mathrm{Tc}$ requires a chelator to conjugate the radioisotope with the target ligand. The combinations of nitrogen, oxygen, and sulfur appear to be stable chelators for ${ }^{99 \mathrm{~m}} \mathrm{Tc}[10-12]$. In fact, this chelator could allow the same target ligand to be labeled with several different radioisotopes, such as gallium-68, indium-111, or rhenium188 , for future diagnostic and therapeutic applications.

Here, we report the synthesis of ${ }^{99 \mathrm{~m}} \mathrm{Tc}$-labeled tyrosine using 1,4,8,11-tetra-azacyclotetradecane (N4) cyclam as a chelator and evaluate its potential in gamma imaging using in vitro and in vivo breast tumor models.

\section{Materials and Methods}

All chemicals of analytical grade and solvents of highperformance liquid chromatography (HPLC) grade were obtained from Sigma-Aldrich (St. Louis, MO, USA). Nuclear magnetic resonance (NMR) was performed on a Bruker 300MHz spectrometer (Bruker BioSpin Corporation, Billerica, MA, USA), and mass spectra were performed on a Waters Q-TOF Ultima mass spectrometer (Waters, Milford, MA, USA) at the chemistry core facility at The University of Texas MD Anderson Cancer Center (Houston, TX, USA). Sodium pertechnetate $\left(\mathrm{Na}^{99 \mathrm{~m}} \mathrm{TcO}_{4}\right)$ was obtained from a ${ }^{99} \mathrm{Mo} /{ }^{99 \mathrm{~m}} \mathrm{Tc}$ generator (Mallinckrodt, Hazelwood, MO, USA). ${ }^{18}$ F-FDG was obtained from the Department of Nuclear Medicine at MD Anderson.

\subsection{Synthesis of Precursor N4-Tyrosine}

2.1.1. N-t-Butoxycarbonyl-O-[3-Br-propyl]-L-tyrosine Methyl Ester (Compound 1). N-t-Butoxycarbonyl-L-tyrosine methyl ester $(25.00 \mathrm{~g} ; 0.085 \mathrm{~mol})$ was dissolved in acetone $(300 \mathrm{~mL})$. 1,3-Dibromopropane $(17.3 \mathrm{~mL} ; 0.169 \mathrm{~mol})$ and $\mathrm{K}_{2} \mathrm{CO}_{3}$ $(58.00 \mathrm{~g} ; 0.420 \mathrm{~mol})$ were added under a nitrogen atmosphere. The reaction mixture was refluxed at $80^{\circ} \mathrm{C}$ overnight. After the mixture was cooled and filtered, the solvent was removed under reduced pressure and the residue was dissolved in chloroform. The residue was washed with water and dried with anhydrous $\mathrm{MgSO}_{4}$. The product was purified by column chromatography using a silica gel column eluted with hexane: ethyl acetate $(2: 1, \mathrm{v} / \mathrm{v})$. Yield: $33.30 \mathrm{~g}(94.60 \%)$. $\mathrm{Ms}(\mathrm{m} / \mathrm{z})=440.09[\mathrm{M}+\mathrm{Na}]^{+}$.
2.1.2. $\quad N^{1}, N^{4}$-Dioxylyl-1,4,8,11-tetraazabicyclotetradecane $\left(N^{1}, N^{4}\right.$-Cyclooxamide) (Compound 2). N4 cyclam (15.00 g; $74.88 \mathrm{mmol}$ ) was dissolved in $150 \mathrm{~mL}$ of anhydrous ethanol, and diethyl oxalate $(10.94 \mathrm{~g} ; 74.88 \mathrm{mmol})$ was added. The reaction mixture was refluxed for 18 hours at $75^{\circ} \mathrm{C}$. The solvent was rotary evaporated, and the crude product was dissolved in minimum quantity of ethanol and filtered and recrystallized in $400 \mathrm{~mL}$ of acetone/ethanol to yield white crystals of compound 2. Yield: $13.64 \mathrm{~g}(71.62 \%)$. Ms (m/z) $255.19[\mathrm{M}]^{+}$.

2.1.3. $N$-t-Butoxycarbonyl-O-[3- $\left(N^{1}, N^{4}\right.$-dioxylyl-1,4,8,11-tetraazabicyclotetradecane)-propyl]-tyrosine Methyl Ester (Compound 3). Compound 2 (0.63 g; $2.46 \mathrm{mmol}$ ) was dissolved in $20 \mathrm{~mL}$ of anhydrous dimethylformamide; it was reacted with a solution of compound $1(1.06 \mathrm{~g} ; 2.46 \mathrm{mmol})$ in $40 \mathrm{~mL}$ of dimethylformamide under a nitrogen atmosphere. The mixture was refluxed at $75^{\circ} \mathrm{C}$ for 18 hours and then cooled to room temperature. The reaction mixture was filtered, and the solvent was removed in vacuo. The crude compound was purified via silica gel column using chloroform: methanol solution $(9: 1, \mathrm{v} / \mathrm{v})$. Yield: $0.65 \mathrm{~g}(1.05 \mathrm{mmol} ; 42.76 \%)$. Ms $(\mathrm{m} / \mathrm{z}) 591.31[\mathrm{M}]^{+}$.

2.1.4. O-[3-( $\mathrm{N}^{1}, \mathrm{~N}^{4}$-Dioxylyl-1,4,8,11-tetraazabicyclotetradecane)-propyl]-tyrosine Methyl Ester (Compound 4). To deprotect $\mathrm{N}$ - $t$-butoxycarbonyl group, Compound 3 (0.60 g; $1.00 \mathrm{mmol}$ ) was dissolved in anhydrous dichloromethane $(15 \mathrm{~mL})$, and $2.5 \mathrm{~mL}$ of trifluoroacetic acid was added to it. The solution was stirred overnight at room temperature, and the solvents were then removed in vacuo. The crude compound was purified by chromatography over silica gel (chloroform: methanol 9:1, v/v) giving an off-white solid. Yield: $0.18 \mathrm{~g}(90 \%)$. Ms (m/z) $490.31[\mathrm{M}]^{+}$.

2.1.5. O-[3-(1,4,8,11-Tetraazabicyclohexadecane)-propyl]-tyrosine (Compound 5, N4-Tyrosine). Compound 4 (0.25 g; $0.50 \mathrm{mmol}$ ) was dissolved in $5 \mathrm{~mL}$ of water, and $2.5 \mathrm{~mL}$ of $10 \mathrm{~N} \mathrm{NaOH}$ was added to it. The solution was stirred and refluxed overnight at $90^{\circ} \mathrm{C}$, and the solvent was evaporated in vacuo. The crude compound was then dissolved in $5 \mathrm{~mL}$ of water, and the $\mathrm{pH}$ of the solution was neutralized to $\mathrm{pH} 7$ by adding $5 \mathrm{M} \mathrm{HCl}$. The final solution was lyophilized overnight to obtain white powder, which was then dissolved in $25 \mathrm{~mL}$ of anhydrous methanol, filtered, evaporated, and lyophilized to obtain off-white powder. Yield: $0.19 \mathrm{~g}(88.78 \%)$. = Ms (m/z) $422.31[\mathrm{M}]^{+}$.

2.2. Radiolabeling of N4-Tyrosine with ${ }^{99 \mathrm{~m}} \mathrm{Tc}$. N4-Tyrosine $(1 \mathrm{mg})$ was dissolved in $0.2 \mathrm{~mL}$ of sterile water, and tin (II) chloride $(0.1 \mathrm{~mL}, 1 \mathrm{mg} / \mathrm{mL})$ was added. The required amount of $\mathrm{Na}^{99} \mathrm{TcO}_{4}$ was added to the N4-Tyrosine solution at the room temperature. Radiochemical purity was determined by radio-HPLC using an C-18 reverse column (Waters), eluted with a $7: 3$ acetonitrile: water solution $(\mathrm{v} / \mathrm{v})$ at a flow rate of $0.5 \mathrm{~mL} /$ minute. 
2.3. Determination of the Partition Coefficient. To determine the lipophilicity, $20 \mu \mathrm{L}$ of ${ }^{99 \mathrm{~m}} \mathrm{Tc}-\mathrm{N} 4$-Tyrosine was added into an equal volume mixture of 1-octanol and sterile water in a centrifuge tube. The mixture was vortexed at room temperature for 1 minute and then centrifuged at 5,000 rpm for 5 minutes to allow phase separation. From each phase, $0.1 \mathrm{~mL}$ of the aliquot was taken out, and the radioactivity was measured by gamma counter (Cobra Quantum, Packard, MN, USA). The measurement was repeated 3 times, and care was taken to avoid cross-contamination between the phases. The partition coefficient value, expressed as $\log P$, was calculated using the following equation:

$$
\log P=\log \left(\frac{\text { radioactivity in 1-octanol layer }}{\text { radioactivity in sterile water layer }}\right)
$$

2.4. In Vitro Cellular Uptake. Rat breast tumor cell line 13762 (American Type Culture Collection, Rockville, MD, USA) was used for both in vitro studies and to create the animal model for in vivo evaluation. All cells were maintained in Dulbecco's modified Eagle's medium and nutrient mixture F-12 Ham (DMEM/F12; GIBCO, Grand Island, NY) at $37^{\circ} \mathrm{C}$ in a humidified atmosphere containing $5 \% \mathrm{CO}_{2}$.

For in vitro cellular uptake analysis, cells were plated onto 6-well tissue culture plates $\left(2 \times 10^{5}\right.$ cells/well $)$ 48 hours before adding the radiotracers and incubated with ${ }^{99 \mathrm{~m}} \mathrm{Tc}$-N4-Tyrosine $(0.05 \mathrm{mg} /$ well, $8 \mu \mathrm{Ci} /$ well $),{ }^{99 \mathrm{~m}} \mathrm{Tc}$ N4 $(0.025 \mathrm{mg} /$ well, $8 \mu \mathrm{Ci} /$ well $)$, or ${ }^{18} \mathrm{~F}-\mathrm{FDG}(8 \mu \mathrm{Ci} /$ well $)$ for 0-4 hours. After incubation, cells were washed with icecold phosphate-buffered solution twice and detached using a treatment of $0.5 \mathrm{~mL}$ of trypsin for 5 minutes. Cells were then collected, and the radioactivity of the cells was measured in triplicate with a gamma counter (Cobra Quantum). Radioactivity was expressed as mean \pm standard deviation (SD) percent of cellular uptake (\%Uptake).

2.5. Blood Clearance. All animal work was carried out in the Small Animal Imaging Facility at MD Anderson under a protocol approved by the Institutional Animal Care and Use Committee. For blood clearance analysis, 3 normal female Fischer 344 rats ( $150 \pm 25$ g; Harlan Sprague-Dawley, Indianapolis, IN, USA) were intravenously injected with $30 \mu \mathrm{Ci}$ of ${ }^{99 \mathrm{~m}} \mathrm{Tc}-\mathrm{N} 4$-Tyrosine. Blood samples $(n=3 / \mathrm{rat})$ were drawn from each rat through the lateral tail vein by microliter pipette $(10 \mu \mathrm{L})$ at several time points between 5 minutes and 24 hours after injection. The blood samples were measured for radioactivity by gamma counter, and the radioactivity was expressed as a percentage of the injected dose per gram of blood (\%ID/g).

2.6. Tissue Distribution. Tissue distribution studies of ${ }^{99 \mathrm{~m}} \mathrm{Tc}$-N4-Tyrosine were conducted using normal female Fischer 344 rats $(150 \pm 25 \mathrm{~g}, n=9)$. The rats were divided into 3 groups, and each rat was injected intravenously with 25 $\pm 0.5 \mu \mathrm{Ci}$ of ${ }^{99 \mathrm{~m}} \mathrm{Tc}-\mathrm{N} 4$-Tyrosine. Each group was examined at 1 of 3 time points $(0.5,2$, or 4 hours after injection). At each time point, the rats were killed, and the selected tissues were excised, weighed, and measured for radioactivity by gamma counter. For each sample, radioactivity was expressed as mean percentage of the injected dose per gram of tissue wet weight $(\% \mathrm{ID} / \mathrm{g})$. Counts from a $1 / 10$ diluted sample of the original injection were used as a reference.

2.7. OLINDA/EXM Dosimetry Estimates. Rat absorbed dose estimates for ${ }^{99 \mathrm{~m}} \mathrm{Tc}-\mathrm{N} 4-$ Tyrosine were computed from biodistribution data. Individual organ and whole-body timeactivity curves were fitted to exponential functions using OLINDA/EXM software (version 1.1; Vanderbilt University, Nashville, TN, USA). These functions were then integrated analytically to determine the area under the curve to yield the residence time of ${ }^{99 \mathrm{~m}} \mathrm{Tc}-\mathrm{N} 4-$ Tyrosine in each organ. It was assumed that the injected activity of ${ }^{99 \mathrm{~m}} \mathrm{Tc}-\mathrm{N} 4$-Tyrosine was uniformly distributed throughout the body immediately following injection. Mass correction factors were used to account for the different ratios of organs to total body weight and different scaling of residence times between rats and humans [13]. Residence times were then used to calculate target organ absorbed radiation doses for a $70 \mathrm{~kg}$ standard man model using the OLINDA/EXM software.

2.8. Planar Scintigraphic Imaging in Breast Tumor-Bearing Rats. Cells from the breast tumor cell line 13762, suspended in phosphate-buffered solution $\left(10^{5}\right.$ cells $/ 0.1 \mathrm{~mL}$ solution per rat), were injected subcutaneously into the right calf muscle of female Fischer 344 rats $(n=9)$. Planar scintigraphic imaging of ${ }^{99 \mathrm{~m}} \mathrm{Tc}-\mathrm{N} 4-$ Tyrosine was performed $12-14$ days after inoculation when tumors reached approximately $1 \mathrm{~cm}$ in diameter. The breast tumor-bearing rats $(n=3 /$ time point) were anesthetized and injected intravenously with ${ }^{99 \mathrm{~m}} \mathrm{Tc}-\mathrm{N} 4-$ Tyrosine $(0.3 \mathrm{mg} / \mathrm{rat}, 300 \mu \mathrm{Ci} / \mathrm{rat})$, and images were acquired at 30, 120, and 240 minutes after administration of tracers. Planar scintigraphic images were obtained using M-CAM (Siemens Medical Solutions, Hoffman Estates, IL, USA) equipped with a low-energy high-resolution collimator. Computer-outlined regions of interest (ROIs in counts per pixel) between tumor and muscle tissue were used to calculate tumor-to-muscle (T/M) ratios. Percent of injected dose (\%ID) in the tumor was also calculated from the reference standard, which was $1 / 10$ of the original injection activity of ${ }^{99 \mathrm{~m}} \mathrm{Tc}-\mathrm{N} 4-$ Tyrosine.

2.9. Tumor and Inflammation Uptake Comparison. To investigate whether ${ }^{99 \mathrm{~m}} \mathrm{Tc}-\mathrm{N} 4-$ Tyrosine can differentiate tumor tissue from inflammatory tissue, a rat model bearing both a mammary tumor and tissue with turpentine oil-induced inflammation was created. Rat breast tumor cells (from cell line $13762 ; 10^{5}$ cells $/ 0.1 \mathrm{~mL}$ phosphate-buffered solution per rat) were injected into the right calf muscles of 3 female Fischer 344 rats. After the tumors reached $1 \mathrm{~cm}$ in diameter, turpentine oil $(0.1 \mathrm{~mL} / \mathrm{rat})$ was injected into the left calf muscles of the rats to induce inflammation. The anesthetized rats were injected intravenously with ${ }^{99 \mathrm{~m}} \mathrm{Tc}$ N4-Tyrosine 24 hours after the turpentine injection. Planar scintigraphic images were acquired at 30, 120, and 240 minutes after the ${ }^{99 \mathrm{~m}} \mathrm{Tc}-\mathrm{N} 4$-Tyrosine injection, and ROIs of the tumor, inflamed tissue, and muscle were used to 
calculate the tumor-to-muscle ratios (T/Ms), inflammationto-muscle ratios (I/Ms), and tumor-to-inflammation ratios (T/Is), respectively. The same animal model was used to evaluate ${ }^{18} \mathrm{~F}-\mathrm{FDG}$. Micro-PET imaging of ${ }^{18} \mathrm{~F}-\mathrm{FDG}$ was performed using an R4 micro-PET scanner (Concorde Microsystems, Knoxville, TN, USA). Three breast tumorand inflammation-bearing rats were injected intravenously with ${ }^{18} \mathrm{~F}-\mathrm{FDG}(500 \mu \mathrm{Ci} / \mathrm{rat})$, and dynamic PET scans with a spatial resolution of $2.2 \mathrm{~mm}$ were obtained at 30,60 , and 90 minutes after ${ }^{18} \mathrm{~F}$-FDG injection. PET images were reconstructed by using the ordered subset expectation maximization (OSEM) algorithm. T/M, I/M, and T/I ratios were calculated using the regional radioactivity concentrations $\left(\mu \mathrm{Ci} / \mathrm{cm}^{3}\right)$ that were estimated from the average pixels within ROIs drawn around the tumor, inflamed tissue, or muscle on transverse slices of the reconstructed image sets.

\section{Results and Discussion}

As mentioned previously, radiolabeled amino acid analogues have shown great potentials in cancer imaging by targeting the increased amino acids uptake in tumor cells. In the present study, we report the synthesis of ${ }^{99 \mathrm{~m}} \mathrm{Tc}$-labeled tyrosine using (N4) cyclam as a chelator and evaluate its potential in breast cancer diagnosis using the breast tumor models in vitro and in vivo.

3.1. Chemistry and Radiochemistry. The total synthesis yield of precursor N4-Tyrosine via our 5-step procedure was 38\%. The synthetic scheme is shown in Figure 1. The structure and purity of N4-Tyrosine were confirmed by ${ }^{1} \mathrm{H}$ - and ${ }^{13} \mathrm{C}-\mathrm{NMR}$, mass spectra, and HPLC. The ${ }^{1} \mathrm{H}-\mathrm{NMR}$ results $\left(\mathrm{D}_{2} \mathrm{O} \delta\right.$, ppm) were as follows: $7.18(\mathrm{~d}, 2 \mathrm{H}$, phenyl ring), $6.95(\mathrm{~d}, 2 \mathrm{H}$, phenyl ring), $4.073\left(\mathrm{t}, 2 \mathrm{H}, \mathrm{O}-\mathrm{CH}_{2}\right), 3.43(\mathrm{t}, 1 \mathrm{H}, \mathrm{CHN}), 2.28-3.00$ ( $\mathrm{m}, 2 \mathrm{OH}, \mathrm{OCH}_{2}$ and $\left.\mathrm{NCH}_{2}-\right), 1.87-1.91\left(\mathrm{~m}, 2 \mathrm{H}, \mathrm{C}-\mathrm{CH}_{2}-\mathrm{C}\right)$, and $1.68-1.79\left(\mathrm{~m}, 4 \mathrm{H}, \mathrm{C}-\mathrm{CH}_{2}-\mathrm{C}\right) .{ }^{13} \mathrm{C}-\mathrm{NMR}$ results $\left(\mathrm{D}_{2} \mathrm{O} \delta\right.$, ppm) were as follows: 162.88, 156.72, 130.76, 117.57, 115.25, 68.55, 57.29, 53.91, 51.56, 49.95, 49.17, 48.96, 48.24, 48.03, $46.80,45.73,45.35,39.27,24.90,24.31$, and 23.87. Because the starting material, $\mathrm{N}$ - $t$-butoxycarbonyl-L-tyrosine methyl ester, was commercially available, the synthetic yield of N4Tyrosine in our study was much higher (38\%) than that of its $\alpha$-methyl derivative N4-AMT (14\%), which was reported in a previous study [14].

For the radiolabeling, the top and middle panels of Figure 2 show the ultraviolet absorbance of $99 \mathrm{~m} \mathrm{Tc}-\mathrm{N} 4-$ Tyrosine at $210 \mathrm{~nm}$ and $274 \mathrm{~nm}$, while the bottom panel indicates the peak from $\mathrm{NaI}$ detector that only detects the radioactivity. Since precursor N4-Tyrosine has a unique ultraviolet absorbance at $274 \mathrm{~nm}$, we selected $274 \mathrm{~nm}$ for one of the ultraviolet detectors. On the other hand, the $210 \mathrm{~nm}$ detector can detect almost every molecule; therefore, we were able to detect any impurities in our compound. The retention time of three detectors matched very well, which indicated precursor N4-Tyrosine was labeled with ${ }^{99 \mathrm{~m}} \mathrm{Tc}$ successfully with high radiochemical purity $(>95 \%)$. Because ${ }^{99 \mathrm{~m}} \mathrm{Tc}-\mathrm{N} 4-$ Tyrosine is a kit product and labeled without any further purification, its radiochemical yield was assumed to be identical to its radiochemical purity. For the partition coefficient value, the $\log P$ of ${ }^{99 \mathrm{~m}} \mathrm{Tc}-\mathrm{N} 4$-Tyrosine was $-2.83 \pm 0.082$, which was lower than that of its $\alpha$ methyl derivative ${ }^{99 \mathrm{~m}} \mathrm{Tc}-\mathrm{N} 4-\mathrm{AMT}(-2.02 \pm 0.168)$. Since the $\log P$ value is positively correlated with lipophilicity of the compound, we found that the lipophilicity of the tyrosine-based radiotracer could be increased by adding a methyl group on its $\alpha$-carbon.

3.2. In Vitro Cellular Uptake Evaluation. The cellular uptake kinetics of ${ }^{99 \mathrm{~m}} \mathrm{Tc}-\mathrm{N} 4$-Tyrosine, ${ }^{99 \mathrm{~m}} \mathrm{Tc}-\mathrm{N} 4$, and ${ }^{18} \mathrm{~F}-\mathrm{FDG}$ in rat breast tumor cells is shown in Figure 3. The uptake for ${ }^{99 m}$ Tc-N4-Tyrosine increased dramatically up to 240 minutes, but this was not true for the ${ }^{99 \mathrm{~m}} \mathrm{Tc}-\mathrm{N} 4$ chelator, suggesting that ${ }^{99 \mathrm{~m}} \mathrm{Tc}-\mathrm{N} 4-$ Tyrosine can enter tumor cells specifically and accumulate rapidly. In addition, the mean $\%$ Uptake of ${ }^{99 \mathrm{~m}} \mathrm{Tc}-\mathrm{N} 4$-Tyrosine was much higher than that of ${ }^{18} \mathrm{~F}-\mathrm{FDG}$, which indicated that ${ }^{99 \mathrm{~m}} \mathrm{Tc}-\mathrm{N} 4$-Tyrosine had better imaging potential than ${ }^{18} \mathrm{~F}-\mathrm{FDG}$ in this in vitro breast cancer model.

3.3. In Vivo Evaluation in Normal Fischer 344 Rats. The blood clearance curve for ${ }^{99 \mathrm{~m}} \mathrm{Tc}-\mathrm{N} 4-\mathrm{Ty}$ rosine in normal Fischer 344 rats is shown in Figure 4. The plasma half-life of the distribution phase $\left(\mathrm{t}_{1 / 2 \alpha}\right)$ was $9.31 \pm 0.759$ minutes, and the plasma half-life of the elimination phase $\left(t_{1 / 2 \beta}\right)$ was $90.14 \pm 1.901$ minutes, indicating that ${ }^{99 \mathrm{~m}} \mathrm{Tc}-\mathrm{N} 4$-Tyrosine had relatively fast blood clearance in normal rats.

Tissue distribution of ${ }^{99 \mathrm{~m}} \mathrm{Tc}-\mathrm{N} 4-$ Tyrosine in normal Fischer 344 rats is shown in Table 1. Low thyroid and stomach uptake of ${ }^{99 \mathrm{~m}} \mathrm{Tc}-\mathrm{N} 4$-Tyrosine was observed, suggesting that ${ }^{99 m}$ Tc-N4-Tyrosine has high stability in vivo. High uptake was found in the kidneys, which was consistent with the planar scintigraphic imaging findings in the breast tumorbearing rats (see Figure 5). This high kidney uptake may be a result of the low lipophilicity of ${ }^{99 \mathrm{~m}} \mathrm{Tc}-\mathrm{N} 4$-Tyrosine, or it may be related to the biological characteristics of ${ }^{99 \mathrm{~m}} \mathrm{Tc}$-labeled tyrosine because similar results were also observed in the previously developed tyrosine-based radiotracers ${ }^{99 \mathrm{~m}} \mathrm{Tc}-\mathrm{N} 4-$ AMT, ${ }^{99 \mathrm{~m}} \mathrm{Tc}-\mathrm{EC}-\mathrm{AMT}$, and ${ }^{99 \mathrm{~m}} \mathrm{Tc}$-EC-Tyrosine $[14,15]$.

To estimate the maximum dose of ${ }^{99 \mathrm{~m}} \mathrm{Tc}-\mathrm{N} 4$-Tyrosine that could be safely administered to humans, individual organ absorbed radiation doses were calculated using OLINDA/EXM software. Estimates of the doses per unit administered are shown in Table 2. The kidneys received the highest absorbed dose $(4.86 E-02 \mathrm{mSv} / \mathrm{MBq}$ or $1.80 E$ $01 \mathrm{rem} / \mathrm{mCi}$ ), which made it the dose-limiting organ. Other organs with relatively high absorbed radiation doses included the heart wall, spleen, and liver. According to the US Food and Drug Administration regulations, human exposure to radiation from the use of "radioactive research drugs" should be limited to 3 rem per single administration and 5 rem per year to the whole body, blood-forming organs (red marrow, osteogenic cells, spleen), the lens of the eye, and gonads (testes and uterus); the limit for other organs is 5 rem per single administration and $15 \mathrm{rem}$ annually. Total rem of ${ }^{99 \mathrm{~m}} \mathrm{Tc}-\mathrm{N} 4$-Tyrosine absorbed by each organ was below these limits at the proposed injection of $15 \mathrm{mCi}$ per patient. 


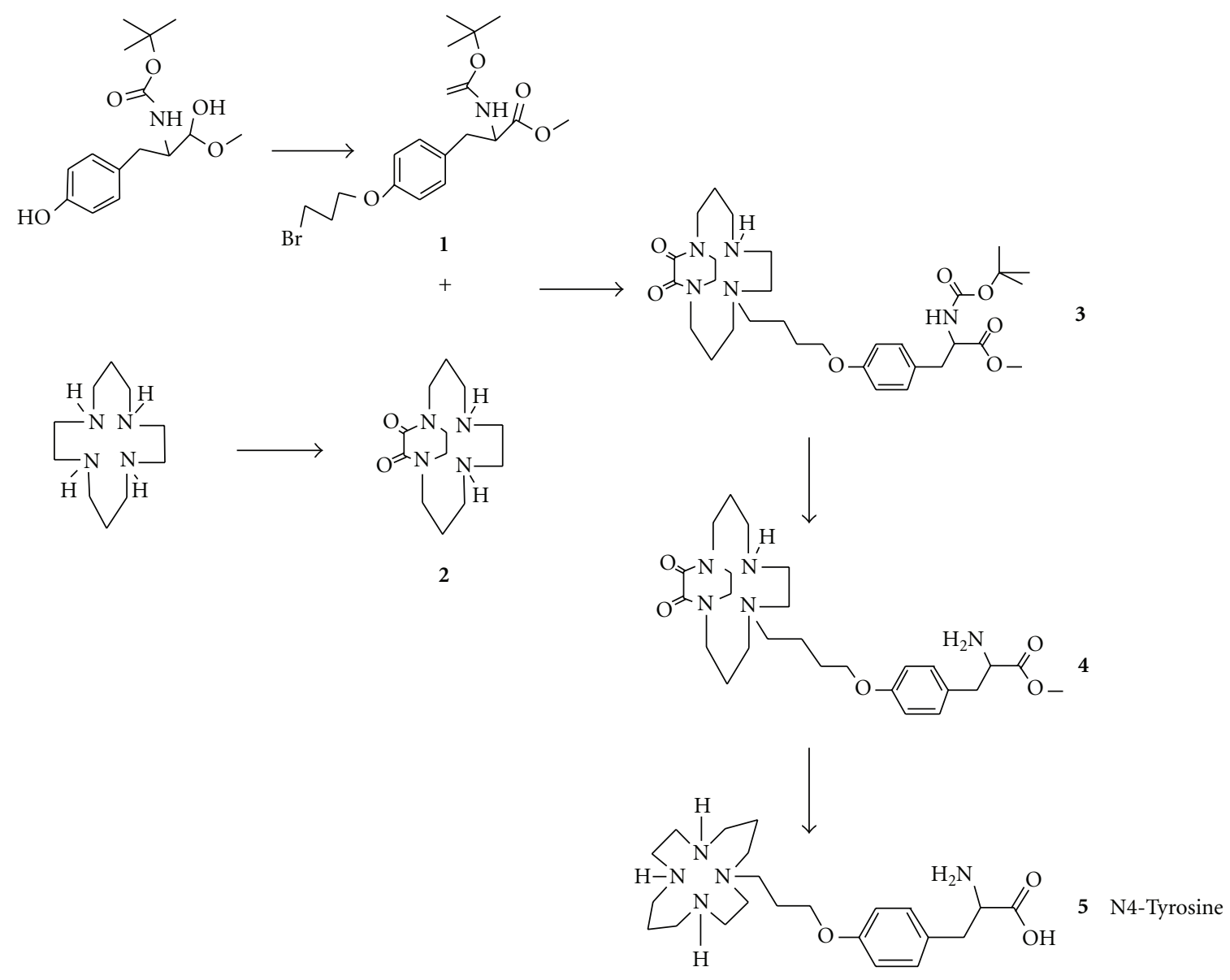

Figure 1: Synthetic scheme of precursor N4-Tyrosine.

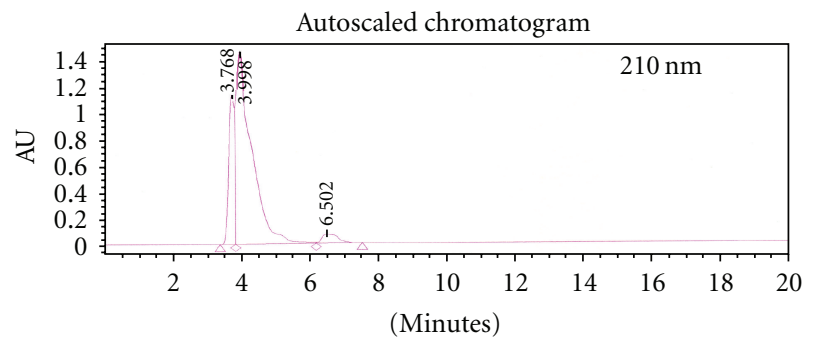

(a)

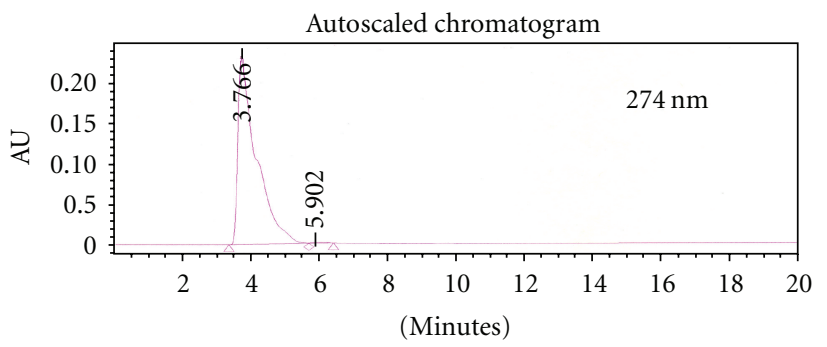

(b)

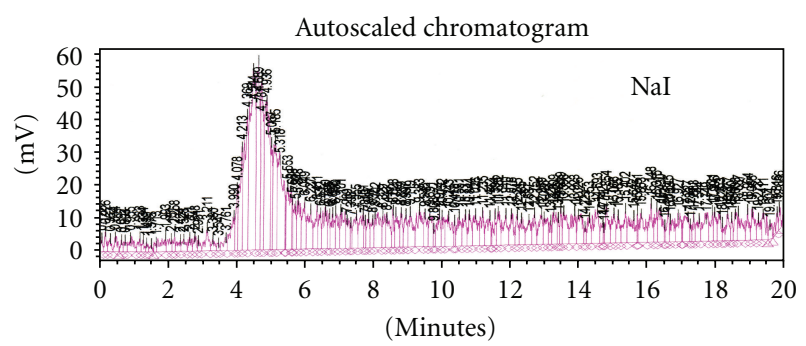

(c)

FIGURE 2: High-performance liquid chromatographic analysis of ${ }^{99 \mathrm{~m}} \mathrm{Tc}-\mathrm{N} 4$-Tyrosine at a flow rate of $0.5 \mathrm{~mL} / \mathrm{minute}$ using a C-18 reverse column under ultraviolet absorbance of $210 \mathrm{~nm}$ (a) and $274 \mathrm{~nm}$ (b), as well as under a NaI radioactivity detector (c). 
TABLE 1: In vivo tissue distribution of ${ }^{99 \mathrm{~m}}$ Tc-N4-Tyrosine in normal Fischer 344 rats $(n=3)$ at 30, 120, and 240 minutes after injection.

\begin{tabular}{|c|c|c|c|c|c|c|}
\hline Organ & 30 & MIN & 120 & MIN & 240 & MIN \\
\hline Blood & 0.88 & \pm 0.040 & 0.20 & \pm 0.018 & 0.17 & \pm 0.009 \\
\hline Heart & 0.21 & \pm 0.022 & 0.06 & \pm 0.003 & 0.05 & \pm 0.003 \\
\hline Lung & 0.50 & \pm 0.023 & 0.19 & \pm 0.011 & 0.14 & \pm 0.006 \\
\hline Thyroid & 0.34 & \pm 0.019 & 0.10 & \pm 0.010 & 0.09 & \pm 0.006 \\
\hline Pancreas & 0.17 & \pm 0.017 & 0.07 & \pm 0.012 & 0.05 & \pm 0.002 \\
\hline Liver & 1.15 & \pm 0.059 & 0.70 & \pm 0.040 & 0.67 & \pm 0.044 \\
\hline Spleen & 0.94 & \pm 0.089 & 0.76 & \pm 0.032 & 0.63 & \pm 0.051 \\
\hline Kidney & 11.05 & \pm 0.783 & 12.34 & \pm 0.502 & 12.40 & \pm 0.405 \\
\hline Stomach & 0.20 & \pm 0.018 & 0.08 & \pm 0.003 & 0.06 & \pm 0.002 \\
\hline Intestine & 0.34 & \pm 0.057 & 0.13 & \pm 0.010 & 0.11 & \pm 0.006 \\
\hline Muscle & 0.07 & \pm 0.007 & 0.03 & \pm 0.002 & 0.02 & \pm 0.001 \\
\hline Bone and joint & 0.24 & \pm 0.021 & 0.15 & \pm 0.008 & 0.12 & \pm 0.008 \\
\hline Brain & 0.03 & \pm 0.001 & 0.02 & \pm 0.001 & 0.01 & \pm 0.001 \\
\hline
\end{tabular}

Each value indicates the percent of injected dose per gram of wet weight $(\% \mathrm{ID} / \mathrm{g}, n=3 /$ time point). Each data represents mean of three measurements with standard deviation.

TABLE 2: Absorbed radiation dose estimates (dose per unit injected into a $70 \mathrm{~kg}$ adult man) for ${ }^{99 \mathrm{~m}} \mathrm{Tc}-\mathrm{N} 4$-Tyrosine.

\begin{tabular}{|c|c|c|c|}
\hline \multirow{2}{*}{ Target organ } & \multicolumn{2}{|c|}{ Absorbed radiation dose estimates } & \multirow{2}{*}{$\begin{array}{c}\text { Human dose }(15 \mathrm{mCi}) \\
\text { rem }\end{array}$} \\
\hline & $\mathrm{mSv} / \mathrm{MBq}$ & $\mathrm{rem} / \mathrm{mCi}$ & \\
\hline Adrenals & $4.65 E-03$ & $1.72 E-02$ & $2.58 E-01$ \\
\hline Brain & $4.69 E-04$ & $1.74 E-03$ & $2.61 E-02$ \\
\hline Breasts & $1.27 E-03$ & $4.72 E-03$ & $7.08 E-02$ \\
\hline Gallbladder wall & $3.79 E-03$ & $1.40 E-02$ & $2.10 E-01$ \\
\hline Lower large intestine wall & $1.62 E-03$ & $6.00 E-03$ & $9.00 E-02$ \\
\hline Small intestine & $2.70 E-03$ & $1.00 E-02$ & $1.50 E-01$ \\
\hline Stomach wall & $2.49 E-03$ & $9.21 E-03$ & $1.38 E-01$ \\
\hline Upper large intestine wall & $2.44 E-03$ & $9.04 E-03$ & $1.36 E-01$ \\
\hline Heart wall & $8.51 E-03$ & $3.15 E-02$ & $4.73 E-01$ \\
\hline Kidneys & $4.86 E-02$ & $1.80 E-01$ & $2.70 E+00$ \\
\hline Liver & $5.52 E-03$ & $2.04 E-02$ & $3.06 E-01$ \\
\hline Lungs & $2.27 E-03$ & $8.41 E-03$ & $1.26 E-01$ \\
\hline Muscle & $1.34 E-03$ & $4.96 E-03$ & $7.44 E-02$ \\
\hline Ovaries & $1.76 E-03$ & $6.53 E-03$ & $9.80 E-02$ \\
\hline Pancreas & $3.76 E-03$ & $1.39 E-02$ & $2.09 E-01$ \\
\hline Red marrow & $1.91 E-03$ & $7.07 E-03$ & $1.06 E-01$ \\
\hline Osteogenic cells & $5.21 E-03$ & $1.93 E-02$ & $2.90 E-01$ \\
\hline Skin & $8.91 E-04$ & $3.30 E-03$ & $4.95 E-02$ \\
\hline Spleen & $5.66 E-03$ & $2.09 E-02$ & $3.14 E-01$ \\
\hline Testes & $7.91 E-04$ & $2.93 E-03$ & $4.40 E-02$ \\
\hline Thymus & $2.29 E-03$ & $8.47 E-03$ & $1.27 E-01$ \\
\hline Thyroid & $1.25 E-03$ & $4.61 E-03$ & $6.92 E-02$ \\
\hline Urinary bladder wall & $1.39 E-03$ & $5.14 E-03$ & $7.71 E-02$ \\
\hline Uterus & $1.77 E-03$ & $6.53 E-03$ & $9.80 E-02$ \\
\hline Total Body & $1.98 E-03$ & $7.32 E-03$ & $1.10 E-01$ \\
\hline Effective dose equivalent & $5.71 E-03$ & $2.11 E-02$ & $3.17 E-01$ \\
\hline Effective dose & $2.19 E-03$ & $8.11 E-03$ & $1.22 E-01$ \\
\hline
\end{tabular}




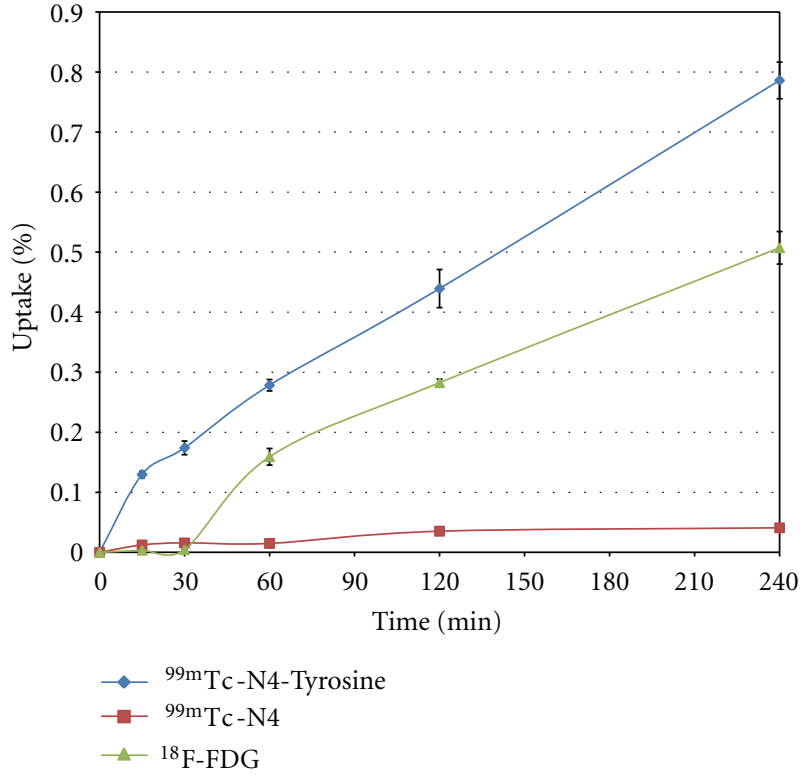

Figure 3: In vitro cellular uptake of ${ }^{99 \mathrm{~m}} \mathrm{Tc}-\mathrm{N} 4$-Tyrosine, ${ }^{99 \mathrm{~m}} \mathrm{Tc}-\mathrm{N} 4$, and ${ }^{18} \mathrm{~F}-\mathrm{FDG}$ in cells from rat breast tumor cell line 13762. Data are expressed as mean percent of cellular uptake \pm standard deviation $(\%$ Uptake \pm SD) measured at 15, 30, 60, 120, and 240 minutes after coincubation with ${ }^{99 \mathrm{~m}} \mathrm{Tc}-\mathrm{N} 4-$ Tyrosine.

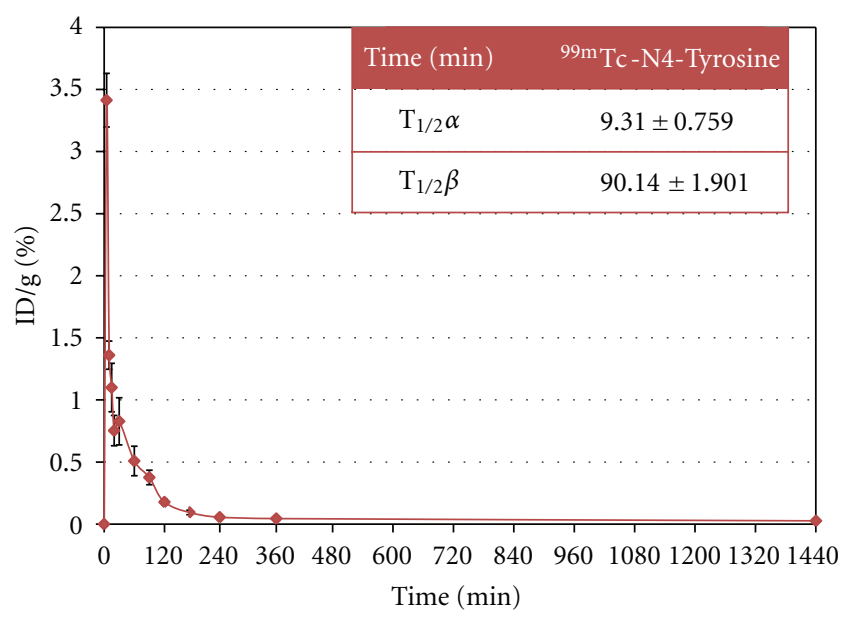

FIgURE 4: Blood clearance curve of ${ }^{99 \mathrm{~m}} \mathrm{Tc}-\mathrm{N} 4$-Tyrosine in normal female Fischer 344 rats $(n=3)$. Mean radioactivity is expressed as mean percentage of the injected dose per gram of blood \pm standard deviation $(\% \mathrm{ID} / \mathrm{g} \pm \mathrm{SD})$.

3.4. In Vivo Evaluation in Breast Tumor-Bearing Rats. The selected planar scintigraphic images of breast tumor-bearing rats at 30, 120, and 240 minutes after ${ }^{99 \mathrm{~m}} \mathrm{Tc}-\mathrm{N} 4$-Tyrosine injection are shown in Figure 5. The T/M ratios at 30, 120, and 240 minutes were 5.12, 4.88, and 5.20, respectively. Tumor $\%$ ID at these three time points were $1.82 \%, 1.87 \%$, and $1.71 \%$, respectively. Tumors could be clearly detected by ${ }^{99 \mathrm{~m}} \mathrm{Tc}-\mathrm{N} 4-\mathrm{Ty}$ rosine at all time points.

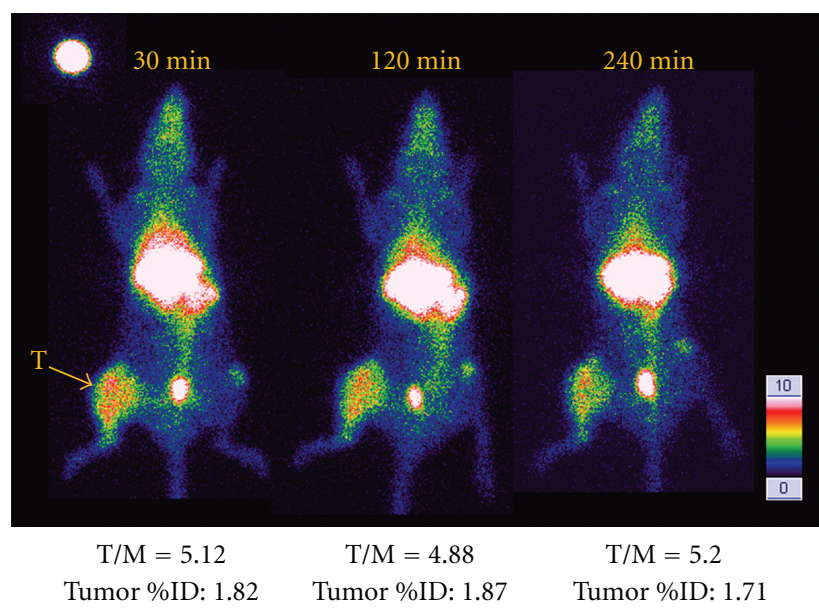

FIGURE 5: The selected planar scintigraphic images of breast tumorbearing rats at 30,120 , and 240 minutes after ${ }^{99 \mathrm{~m}} \mathrm{Tc}-\mathrm{N} 4$-Tyrosine injection ( $\mathrm{T}$ indicates tumor; $\mathrm{T} / \mathrm{M}$, tumor-to-muscle ratio; tumor $\%$ ID, percent of injected dose in the tumor).

The selected planar scintigraphic images of breast tumorand inflammation-bearing rats at 30,120, and 240 minutes after ${ }^{99 \mathrm{~m}} \mathrm{Tc}-\mathrm{N} 4$-Tyrosine injection, as well as micro-PET images at 30, 60, and 90 minutes after ${ }^{18} \mathrm{~F}$-FDG injection, are shown in Figure 6. The T/M ratio of ${ }^{99 \mathrm{~m}} \mathrm{Tc}-\mathrm{N} 4$-Tyrosine was relatively higher than $\mathrm{I} / \mathrm{M}$ ratio at each time point. Although T/I ratios were greater than 1 at all time points for both ${ }^{99 \mathrm{~m}} \mathrm{Tc}-\mathrm{N} 4$-Tyrosine and ${ }^{18} \mathrm{~F}-\mathrm{DFG}$, indicating that the tumor had higher uptake than the inflammation site, the $\mathrm{T} / \mathrm{I}$ ratios for ${ }^{99 \mathrm{~m}} \mathrm{Tc}-\mathrm{N} 4$-Tyrosine were lower than those for ${ }^{18} \mathrm{~F}$-FDG. This suggests that ${ }^{99 \mathrm{~m}} \mathrm{Tc}-\mathrm{N} 4-$ Tyrosine was inferior to ${ }^{18} \mathrm{~F}-\mathrm{FDG}$ in differentiating tumor from inflammation in this breast tumor-bearing rat model. However, we used turpentine to induce inflammation chemically in this model. It may be worth testing ${ }^{99 \mathrm{~m}} \mathrm{Tc}-\mathrm{N} 4$-Tyrosine in another animal model using radiation to induce inflammation so that the model better mimics patients undergoing radiation therapy.

\section{Conclusion}

In summary, N4-Tyrosine was synthesized and labeled efficiently with ${ }^{99 \mathrm{~m}} \mathrm{Tc}$ with high radiochemical purity. Although it appears to inferior ${ }^{18} \mathrm{~F}-\mathrm{FDG}$ in distinguishing breast tumor tissue from chemical-induced inflammatory tissue, ${ }^{99 \mathrm{~m}} \mathrm{Tc}-$ N4-Tyrosine has high tumor-to-muscle uptake ratios and can detect breast tumor tissue clearly by gamma camera. By taking the advantage of chelator N4 cyclam, we could label N4-Tyrosine with gallium-68 for PET imaging and, furthermore, labeled with rhenium-188 for radionuclide therapy for breast cancer treatment in future.

\section{Authors' Contribution}

F. -L. Kong and M S. Ali contributed equally to this work. 

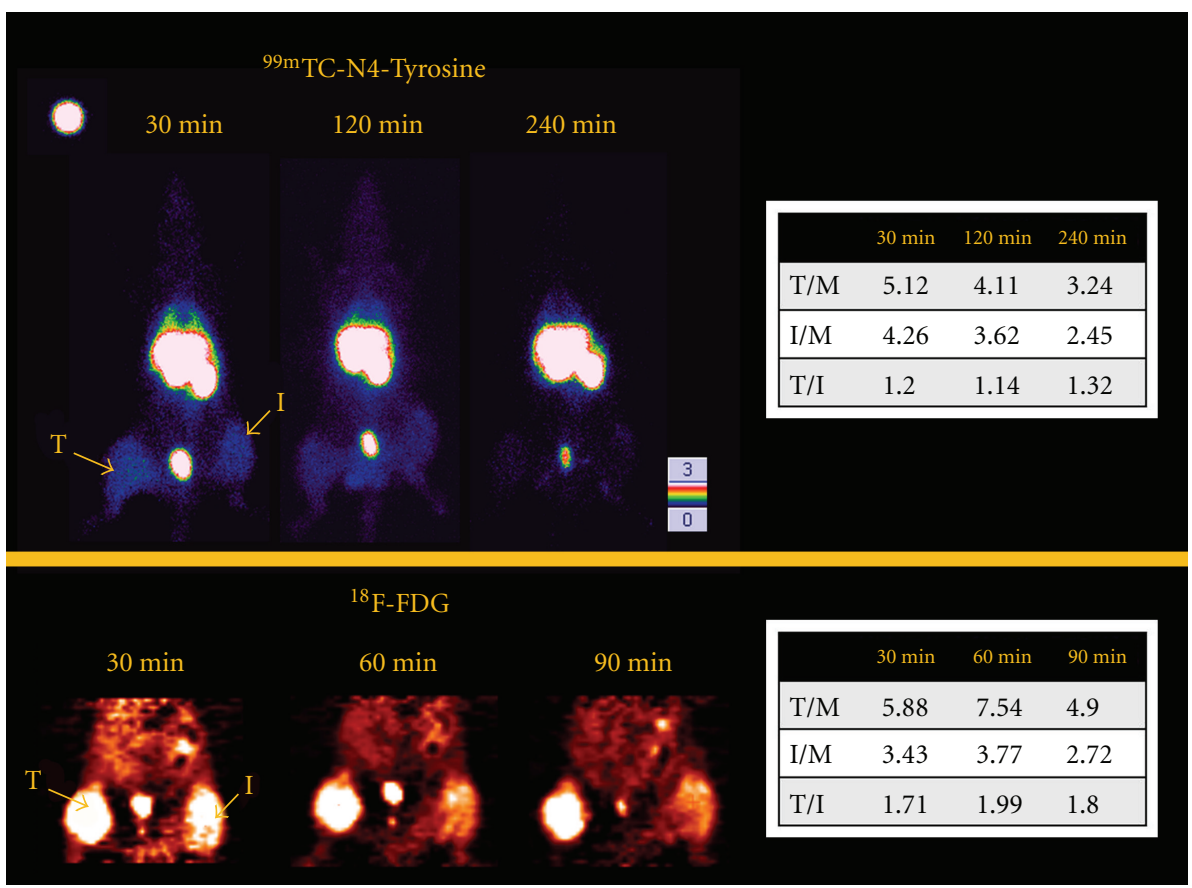

Figure 6: The selected planar scintigraphic images of breast tumor- and inflammation-bearing rats at 30, 120, and 240 minutes after ${ }^{99 \mathrm{~m}} \mathrm{Tc}-$ N4-Tyrosine injection and micro-PET images at 30, 60, and 90 minutes after ${ }^{18} \mathrm{~F}-\mathrm{FDG}$ injection (T indicates tumor; I, inflammation). Tumor-to-muscle (T/M), inflammation-to-muscle (I/M), and tumor-to-inflammation (T/I) ratios are shown in the tables.

\section{Acknowledgments}

This work was supported in part by a sponsored research agreement with Cell > Point L.L.C. (MDA LS200500012803PL) and the John S. Dunn Foundation. The NMR, mass spectrometry, and animal research were supported by the MD Anderson Cancer Center Support Grant CA016672 from the National Institutes of Health.

\section{References}

[1] S. J. Rosenbaum, T. Lind, G. Antoch, and A. Bockisch, "Falsepositive FDG PET uptake-the role of PET/CT," European Radiology, vol. 16, no. 5, pp. 1054-1065, 2006.

[2] P. L. Jager, W. Vaalburg, J. Pruim, E. G. de Vries, K. J. Langen, and D. A. Piers, "Radiolabeled amino acids: basic aspects and clinical applications in oncology," Journal of Nuclear Medicine, vol. 42, no. 3, pp. 432-445, 2001.

[3] K. J. Langen, K. Hamacher, M. Weckesser et al., " $O(2-$ $\left[{ }^{18} \mathrm{~F}\right]$ fluoroethyl)-L-tyrosine: uptake mechanisms and clinical applications," Nuclear Medicine and Biology, vol. 33, no. 3, pp. 287-294, 2006.

[4] K. J. Langen, D. Pauleit, H. H. Coenen et al., "3-[ $\left.{ }^{123} \mathrm{I}\right]$ Iodo$\alpha$-methyl-L-tyrosine: uptake mechanisms and clinical applications," Nuclear Medicine and Biology, vol. 29, no. 6, pp. 625$631,2002$.

[5] R. Boni, H. Steinert, R. Huch Boni et al., "Radioiodinelabelled alpha-methyl-tyrosine in malignant melanoma: cell culture studies and results in patients," British Journal of Dermatology, vol. 137, no. 1, pp. 96-100, 1997.

[6] K. Kaira, N. Oriuchi, Y. Otani et al., "Fluorine-18- $\alpha$ methyltyrosine positron emission tomography for diagnosis and staging of lung cancer: a clinicopathologic study," Clinical Cancer Research, vol. 13, no. 21, pp. 6369-6378, 2007.

[7] H. Tsukada, K. Sato, D. Fukumoto, S. Nishiyama, N. Harada, and T. Kakiuchi, "Evaluation of $\mathrm{D}$-isomers of $\mathrm{O}-{ }^{11} \mathrm{C}$ tyrosine and $O-{ }^{18} \mathrm{~F}$ tyrosine as tumor-imaging agents in tumor-bearing mice: comparison with L- and D-11 C-methionine," Journal of Nuclear Medicine, vol. 47, no. 4, pp. 679-688, 2006.

[8] A. C. Kole, O. E. Nieweg, J. Pruim et al., "Standardized uptake value and quantification of metabolism for breast cancer imaging with FDG and L- $\left[1-{ }^{11} \mathrm{C}\right]$ tyrosine PET," Journal of Nuclear Medicine, vol. 38, no. 5, pp. 692-696, 1997.

[9] S. Jurisson, C. Cutler, and S. V. Smith, "Radiometal complexes: characterization and relevant in vitro studies," Quarterly Journal of Nuclear Medicine and Molecular Imaging, vol. 52, no. 3, pp. 222-234, 2008.

[10] J. David, J. L. B. Yang, and E. Edmund Kim, "Chelator-based imaging technology: new molecular imaging agents provide answers," Imaging Economics, 2006.

[11] C. J. Anderson, C. S. John, Y. J. Li et al., "N, N'-Ethylene-diL-cysteine (EC) complexes of Ga(III) and In(III): molecular modeling, thermodynamic stability and in vivo studies," Nuclear Medicine and Biology, vol. 22, no. 2, pp. 165-173, 1995.

[12] S. Liu, "Bifunctional coupling agents for radiolabeling of biomolecules and target-specific delivery of metallic radionuclides," Advanced Drug Delivery Reviews, vol. 60, no. 12, pp. 1347-1370, 2008.

[13] D. J. Macey, L. E. Williams, H. B. Breitz, A. Liu, T. K. Johnson, and P. B. Zanzonico, A Primer for Radioimmunotherapy and Radionuclide Therapy, 2001.

[14] F. L. Kong, M. S. Ali, Y. Zhang et al., "Synthesis and evaluation of amino acid-based radiotracer ${ }^{99 \mathrm{~m}} \mathrm{TcTc}-\mathrm{N} 4-\mathrm{AMT}$ for breast 
cancer imaging," Journal of Biomedicine and Biotechnology, vol. 2011, Article ID 276907, 2011.

[15] F. L. Kong, Y. Zhang, M. S. Ali et al., "Synthesis of ${ }^{99 \mathrm{~m}} \mathrm{TcTc}$ EC-AMT as an imaging probe for amino acid transporter systems in breast cancer," Nuclear Medicine Communications, vol. 31, no. 8, pp. 699-707, 2010. 


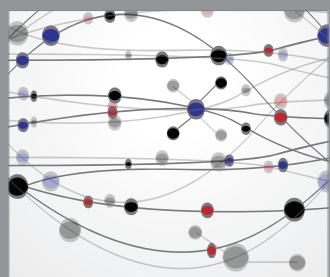

The Scientific World Journal
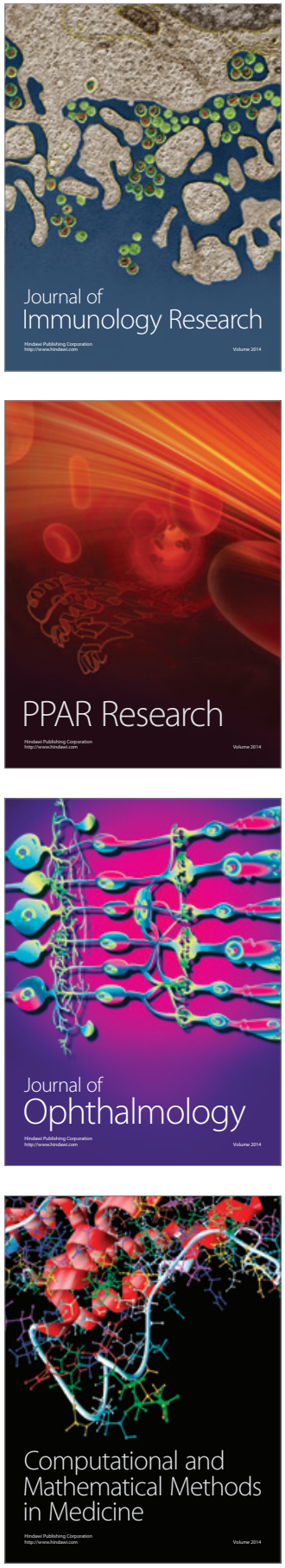

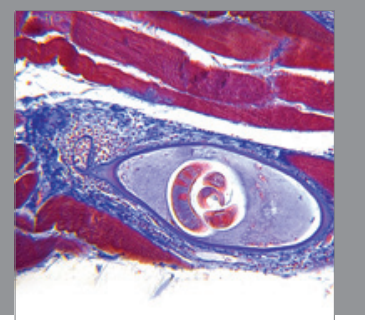

Gastroenterology

Research and Practice
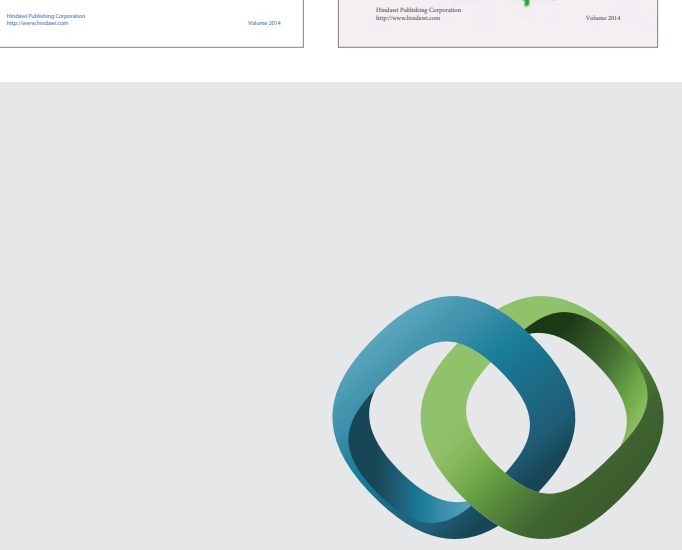

\section{Hindawi}

Submit your manuscripts at

http://www.hindawi.com
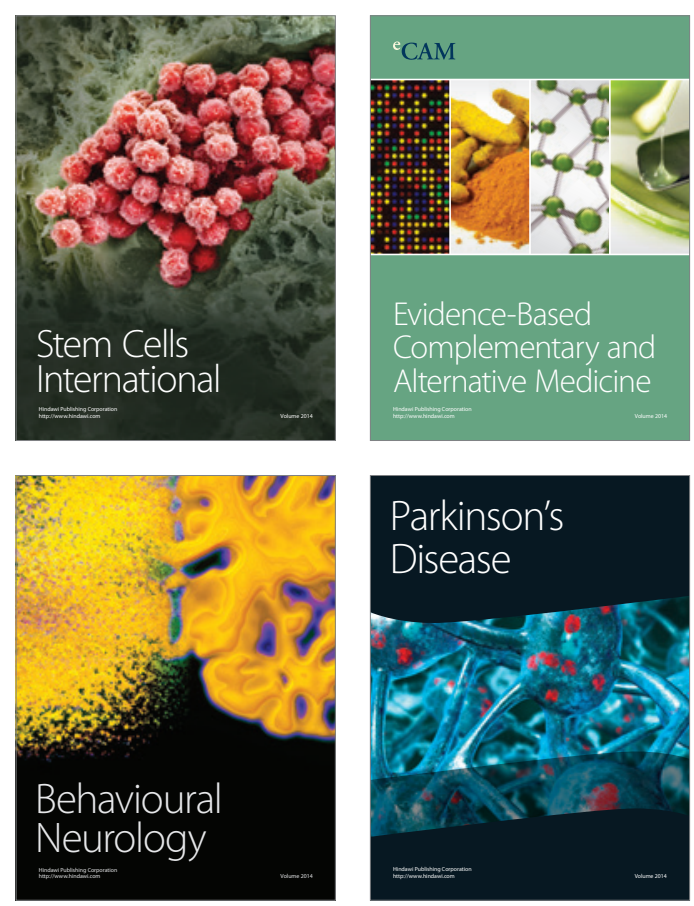

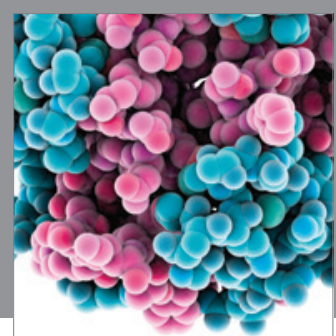

Journal of
Diabetes Research

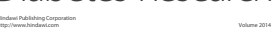

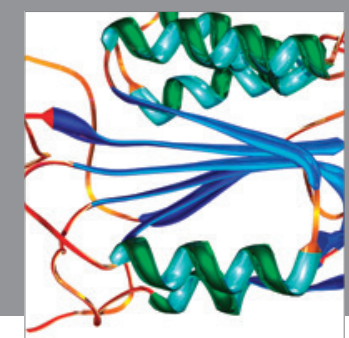

Disease Markers
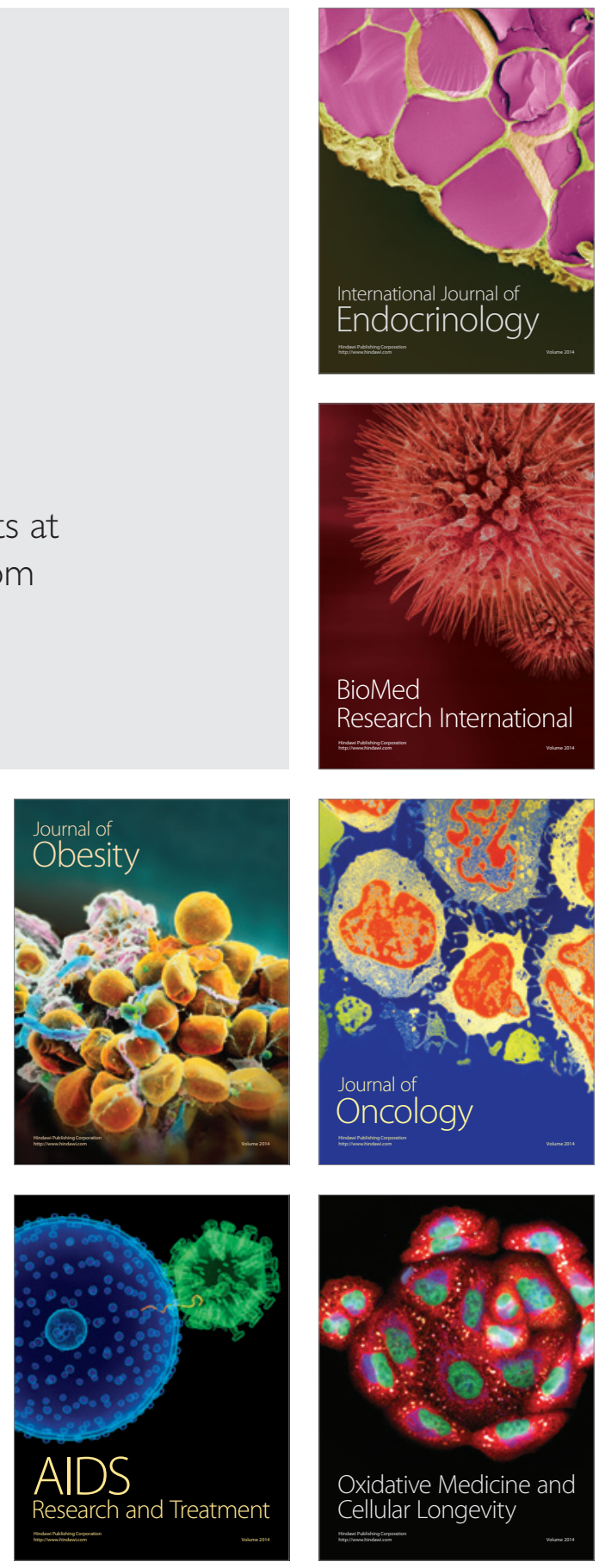